\title{
Lung Function and Severity of Mitral Stenosis
}

\author{
Mahmoud M. Nour Hani Shuhaiber Abdul Mohsen Yousof \\ Chest Disease Hospital, Kuwait
}

\section{Key Words}

Rheumatic mitral stenosis · Pulmonary

function $\cdot$ Respiratory symptoms

\begin{abstract}
Objective: To correlate the degree of severity in patients with rheumatic mitral stenosis to pulmonary function data and to their respiratory symptoms. Methods: Pulmonary function and the MCR questionnaire on respiratory symptoms were made in 43 patients with simple mitral stenosis (SMS), and 79 patients with advanced mitral stenosis scheduled for valve replacement surgery (MVR). Results: All the patients in the two groups had restrictive and obstructive patterns. They had reduced forced vital capacity (FVC), forced expiratory volume in $1 \mathrm{~s}\left(\mathrm{FEV}_{1}\right)$, peak expiratory flow rate, maximal flow after exhalation of 75,50 and $25 \%$ of FVC and single-breath carbon monoxide diffusing capacity ( $\mathrm{DL}_{\mathrm{co}}$ ) and increased total airway resistance, resistance during expiration, and residual volume (RV). The SMS group tended toward more
\end{abstract}

\begin{tabular}{ll}
\hline KARGER & (1) 1999 S. Karger AG, Basel \\
Fax +41 61 306 1234 34 & \\
$\begin{array}{l}\text { E-Mail karger@karger.ch } \\
\text { www.karger.com }\end{array}$ & $\begin{array}{l}\text { Accessible online at: } \\
\text { http://BioMedNet.com/karger }\end{array}$
\end{tabular}

normal values. The MVR group had lower values for all the parameters, specially FVC, $\mathrm{FEV}_{1}, \mathrm{DL}_{\mathrm{CO}}$ and higher RV. The MVR group had a significantly higher prevalence of cough, phlegm and acute chest illness than the SMS group. Conclusion: The study confirmed the restrictive and obstructive pattern of pulmonary dysfunction in patients with rheumatic mitral stenosis which related with the severity of mitral stenosis and with respiratory symptoms.

\section{Introduction}

There has often been a discrepancy between the assessment of the severity of mitral stenosis by symptoms and assessment by measurement of lung function [1-3]. Although some relationship had been shown between lung function and severity of dyspnoea, this does not necessarily give information about the cardiac contribution since both could reflect respiratory involvement $[4,5]$. 
The interrelation between the cardiac and the respiratory system is evident from similar symptoms in cardiopulmonary diseases such as chronic cough, haemoptysis, dyspnoea, orthopnoea, shortness of breath with exercise and wheezing [6,7]. The first attempt to explain the mechanism of respiratory symptoms due to cardiac diseases was based on post-mortem studies of the lungs [8].

Earlier workers correlated pulmonary function data to the chronicity of mitral stenosis. Reduction in vital capacity (VC) was more severe in patients with advanced disease [9]. Reduction of VC and total lung capacity (TLC) and an increase in residual volume (RV) were more in patients with long-standing disease [4]. Palmer et al. [5] observed a poor correlation between pre-operative VC and the severity of dyspnoea in patients with mitral stenosis. Cosby et al. [10] reported that the degree of dyspnoea showed a closer relation to the height of pulmonary artery pressure and to VC, than to maximum breathing capacity in the pure mitral stenosis patients [10]. Dogliotti et al. [11] reported reduction of VC, RV, TLC and maximum breathing capacity in mitral stenosis patients with more severe disease, according to the mitral valve area measured at operation. In the previous study, we showed significant correlation of the pre-operative lung function status to the haemodynamic data in advanced mitral stenosis [12].

The aim of this study was to evaluate the disturbances of pulmonary function and the severity of rheumatic mitral stenosis in a group of patients with simple mitral stenosis (SMS) and in another group with advanced stenosis who required mitral valve replacement surgery (MVR). We also attempted to correlate the severity of respiratory symptoms in these two groups of patients with lung function parameters.

Lung Function and Severity of Mitral Stenosis

\section{Method}

Patients

Pulmonary function studies were performed on 43 patients with SMS, diagnosed on the basis of history, clinical assessment and echocardiography [13]. Another group of patients consisted of 79 patients with advanced mitral stenosis who required MVR. The indications for surgery were effort intolerance and evidence of significant haemodynamic derangements obtained at catheterization and angiocardiography [14]. The age and sex distribution are shown in table 1 . Twenty-three patients in the SMS group and 36 patients in the MVR group answered the MRC questionnaire on respiratory symptoms (1965) at the time of performing the lung function tests [15]. None of the patients were smokers, or had a history of asthma or any primary lung disease.

\section{Calibration and Standardization}

The pneumotachographs and pressure transducers were calibrated with standard flow rates, volumes, and pressures. The carbon monoxide and helium analysers were calibrated with standard gases. The ambient temperature, barometric pressure, and the patient's weight, height, age, and sex were entered and the printout values for all pulmonary function data were obtained as actual values at BTPS, and as percent of predicted using prediction nomograms for $\mathrm{VC}$ and forced expired volume in $1 \mathrm{~s}\left(\mathrm{FEV}_{1}\right)$ [16], flow volume curve parameters [17], TLC and RV [18] and diffusing capacity $\left(\mathrm{DL}_{\mathrm{CO}}\right)[19,20]$.

\section{Pulmonary Function Tests}

All subjects in the MVR group were receiving digoxin and diuretics, and none of them was considered to be in cardiac failure. Pulmonary function tests were done during the morning in a sitting position a few days before the cardiac surgery. The studies were performed with a computerized pulmonary function system (Jaeger, Würzburg, Germany). Measurement of VC, maximal voluntary ventilation (MVV), and flow volume curves obtained using a pneumotachograph, and the manoeuvres were monitored on an oscilloscope screen and $\mathrm{X}-\mathrm{Y}$ recorder. Three to five $\mathrm{VC}$ and forced vital capacity (FVC) manoeuvres were perforemed, with a period of rest in-between, and the values were digitized to give FVC, MVV, $\mathrm{FEV}_{1}, \mathrm{FEV}_{1} / \mathrm{FVC}$ ratio, peak expiratory flow rate (PEFR), and flow rates at 75,50 and $25 \%$ of expired VC, corrected to BTPS $\left(\mathrm{Vmax}_{75}, \mathrm{Vmax}_{50}, \mathrm{Vmax}_{25}\right.$, respectively). Airway resistance $\left(R_{\text {tot }}\right.$ and $\left.R_{\text {ex }}\right)$ and the thoracic gas volume at which airway resistance was determined were mea-

Med Principles Pract 1999;8:32-39 
Fig. 1. Frequency distribution histogram of lung function test parameters of patients with SMS and MVR. Values are expressed as \% predicted except for airway resistance $\left(\mathrm{cm} \mathrm{H} \mathrm{H}_{2} \mathrm{O} / \mathrm{l} / \mathrm{s}\right)$.

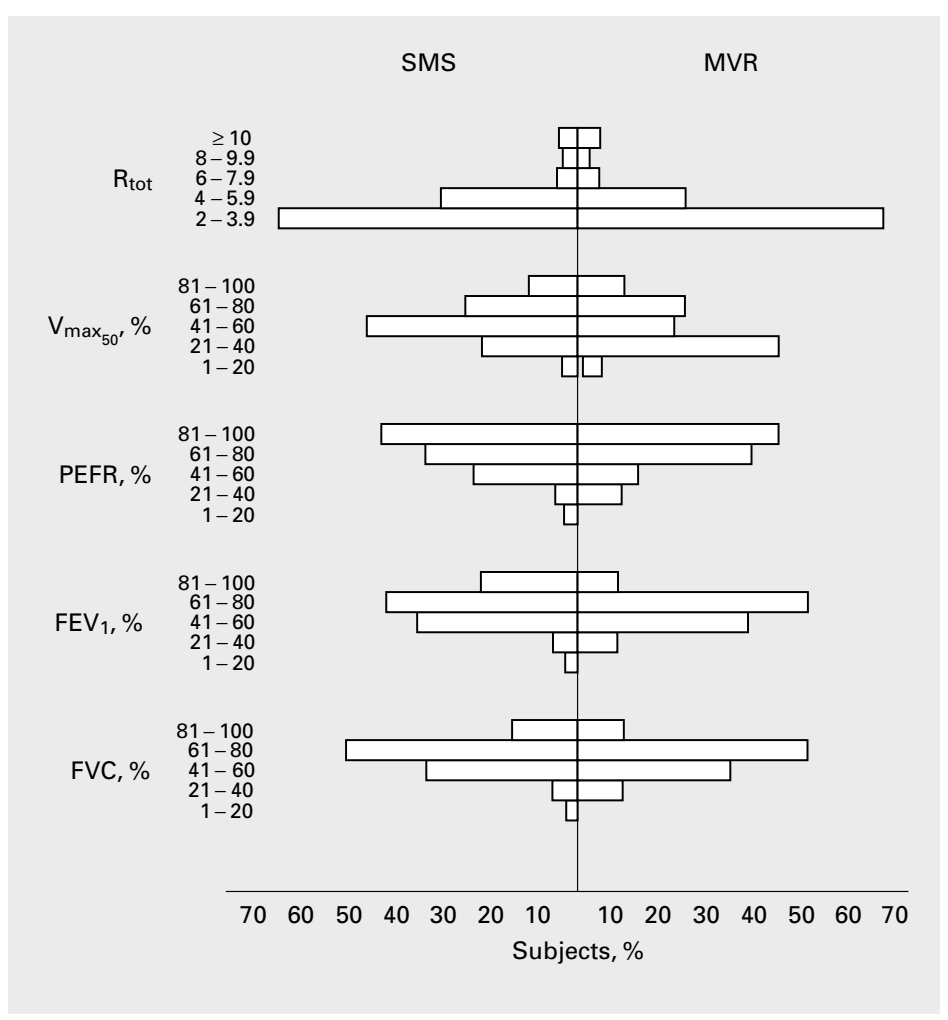

sured according to the methods of DuBois et al. [21] using the constant whole-body plethysmograph, as described by Schmidt and Cohn [22]. After temperature equilibration, 5 loops were made, the results were digitized, and the best loop was selected for analysis, as visually determined on the $\mathrm{X}-\mathrm{Y}$ recorder, where the flow rate during shallow rapid breathing did not exceed \pm 0.5 litres $/ \mathrm{s}$. The resistance values were automatically calculated for total airway resistance during expiration $\left(\mathrm{R}_{\mathrm{ex}}\right)$. Diffusing capacity and residual volume were measured by carbon monoxide transfer and helium dilution, respectively. The single breath method was used, except in patients whose pre-operative VC was less than 1.5 litres and for these patients, the steady-state method was used.

\section{Statistical Analysis}

Independent $t$ test was used to test the significant differences between the two independent groups. Probabilities are expressed conventionally as proportions. A probability ( $\mathrm{p}$ ) value as statistically significant was indicated as $\mathrm{p}<0.05, \mathrm{p}<0.01$ and $\mathrm{p}<0.001$. Chi- square test was used to compare the prevalence of symptoms among the SMS and MVR groups [23], and when any of the expected frequencies was below 5 , Fisher's exact test was relied on, instead.

\section{Results}

The frequency distribution of lung function data in SMS and MVR groups is shown in figure 1. In the SMS group it can be noted that $85 \%$ of the patients had a reduced FVC to less than $80 \%$ of predicted. For FEV ${ }_{1}$, PEFR and $\mathrm{Vmax}_{50}, 80,58$ and $90 \%$ of patients had values less than $80 \%$ of the predicted, respectively. In the MVR group, it is noted that $90 \%$ of the patients had FVC less than $80 \%$ of predicted for FEV 1 , PEFR and $\operatorname{Vmax}_{50}, 92,55$ and $90 \%$ of patients had values less than $80 \%$ 
Table 1. Comparison of pre-operative lung function test values for patients scheduled for MVR and those with SMS

\begin{tabular}{|c|c|c|c|c|c|c|c|c|c|c|c|c|}
\hline Number & $\begin{array}{l}\text { Age } \\
\text { years }\end{array}$ & $\begin{array}{l}\text { Height } \\
\mathrm{cm}\end{array}$ & $\begin{array}{l}\text { FVC } \\
\% \\
\text { pred }\end{array}$ & $\begin{array}{l}\text { RV } \\
\% \\
\text { pred }\end{array}$ & $\begin{array}{l}\text { TLC } \\
\% \\
\text { pred }\end{array}$ & $\begin{array}{l}\text { MVV } \\
\% \\
\text { pred }\end{array}$ & $\begin{array}{l}\mathrm{DL}_{\mathrm{CO}} \\
\% \\
\text { pred }\end{array}$ & $\begin{array}{l}\mathrm{FEV}_{1} \\
\% \\
\text { pred }\end{array}$ & $\begin{array}{l}\text { PEFR } \\
\% \\
\text { pred }\end{array}$ & $\begin{array}{l}\mathrm{Vmax}_{50} \\
\% \\
\text { pred }\end{array}$ & $\begin{array}{l}\mathrm{R}_{\mathrm{tot}} \\
\mathrm{cm} \mathrm{H} \mathrm{H}_{2} \mathrm{O} / \\
\mathrm{c} / \mathrm{sec}\end{array}$ & $\begin{array}{l}\mathrm{R}_{\mathrm{ex}} \\
\mathrm{cm} \mathrm{H} \mathrm{H}_{2} \mathrm{O} / \\
1 / \mathrm{s}\end{array}$ \\
\hline \multicolumn{13}{|l|}{ Males } \\
\hline \multirow[t]{2}{*}{ SMS 17} & 37.1 & 169.2 & 75.9 & 112.7 & 86.7 & 79.5 & 79.0 & 77.7 & 88.9 & 61.7 & 3.75 & 5.05 \\
\hline & \pm 12.3 & \pm 5.8 & \pm 16.4 & \pm 24.4 & \pm 11.1 & \pm 17.9 & \pm 20.9 & \pm 16.6 & \pm 14.3 & \pm 19.8 & \pm 1.83 & \pm 2.64 \\
\hline \multirow[t]{2}{*}{ MVR 35} & 32.7 & 168.5 & 63.5 & 134.0 & 82.3 & 77.8 & 65.0 & 67.4 & 77.7 & 60.1 & 2.99 & 5.07 \\
\hline & \pm 11.7 & \pm 9.5 & \pm 14.5 & \pm 43.4 & \pm 11.7 & \pm 23.3 & \pm 15.9 & \pm 17.6 & \pm 28.1 & \pm 20.5 & \pm 1.49 & \pm 3.36 \\
\hline $\mathrm{p}$ & NS & NS & $<0.01$ & $<0.05$ & NS & NS & $<0.01$ & $<0.05$ & NS & NS & NS & NS \\
\hline \multicolumn{13}{|l|}{ Females } \\
\hline \multirow[t]{2}{*}{ SMS 26} & 39.8 & 159.6 & 75.5 & 105.6 & 89.5 & 70.2 & 72.0 & 74.5 & 79.3 & 64.7 & 4.03 & 5.95 \\
\hline & \pm 12.0 & \pm 6.2 & \pm 16.9 & \pm 35.7 & \pm 12.9 & \pm 21.2 & \pm 21.8 & \pm 20.2 & \pm 16.2 & \pm 19.7 & \pm 2.05 & \pm 3.11 \\
\hline \multirow[t]{2}{*}{ MVR 44} & 34.5 & 157.0 & 67.0 & 116.0 & 85.3 & 70.6 & 64.9 & 67.8 & 77.1 & 60.4 & 4.02 & 6.57 \\
\hline & \pm 11.4 & \pm 5.9 & \pm 14.4 & \pm 48.3 & \pm 17.2 & \pm 19.5 & \pm 20.1 & \pm 17.3 & \pm 20.1 & \pm 20.1 & \pm 1.26 & \pm 2.37 \\
\hline $\mathrm{p}$ & NS & NS & $<0.05$ & NS & NS & NS & NS & $<0.05$ & NS & NS & NS & NS \\
\hline
\end{tabular}

FVC = Forced vital capacity; RV = residal volume; TLC = total lung capacity; MWV = maximal voluntary ventilation; $\mathrm{DL}_{\mathrm{CO}}=$ gas transfer; $\mathrm{FEV}_{1}=$ forced expiratory volume in $1 \mathrm{~s} ; \mathrm{PEFR}=$ peak expiratory flow rate; $\mathrm{Vmax}_{50}=$ flow rate at $50 \%$ of $\mathrm{FVC} ; \mathrm{R}_{\mathrm{tot}}=$ total airway resistance; $\mathrm{R}_{\mathrm{ex}}=$ resistance during expiration.

Values are mean of percent predicted \pm SD. Probability values are for comparing the MVR group with the SMS group in both males and females.

predicted, respectively. None of the differences between the SMS and MVR groups reached the level of statistical significance. Table 1 shows the comparison of the lung function parameters of patients in SMS and MVR groups as divided into male and female groups. It can be seen that both the groups had reduced FVC, MVV, $\mathrm{DL}_{\mathrm{CO}}, \mathrm{FEV}_{1}$, PEFR and $\mathrm{Vmax}_{50}$, and increased RV and expiratory airway resistance. It can be noted that the male patients of the SMS group had statistically significant higher values for FVC $(p<0.01)$, $\mathrm{DL}_{\mathrm{CO}}(\mathrm{p}<0.01), \mathrm{FEV}_{1}(\mathrm{p}<0.05)$ and significantly smaller RV $(p<0.05)$. Comparison of female patients in the SMS and MVR groups showed that the SMS group had significantly higher values for FVC and $\mathrm{FEV}_{1}(\mathrm{p}<0.05)$ when compared to the MVR group.

The frequency of symptoms among the SMS and MVR groups irrespective of their sex is compared in table 2 . It can be noted that there were more patients in the MVR group complaining of acute chest illness (acute bronchitis), than in the SMS group to significant level $(p<0.01)$, as well as from cough and phlegm $(\mathrm{p}<0.05)$. Dyspnoea and wheezing were common symptoms but there were no significant differences between MVR and SMS groups. Chronic bronchitis was the least common complaint in both groups. There was no significant difference in the prevalence of respiratory symptoms between the males and females in the two groups studied.

\section{Discussion}

This study revealed an obstructive ventilatory impairment in patients with mitral stenosis, decreased flow rates (PEFR, $\max _{50}$ ), decreased $\mathrm{FEV}_{1} / \mathrm{FVC}$ ratio, increased thoracic gas volume and airway resistance. It also re- 
Table 2. Number of patients for various respiratory symptoms for SMS and MVR groups

\begin{tabular}{llrrrrr}
\hline Symptom & Group & Yes & No & Total & $\begin{array}{l}\text { Chi- } \\
\text { square } \\
\text { test }\end{array}$ & $\begin{array}{l}\text { p } \\
\text { value }\end{array}$ \\
& & & & & & \\
\hline Cough & SMS & 1 & 22 & 23 & & $<0.05^{*}$ \\
& MVR & 10 & 26 & 36 & & \\
\hline Phlegm & SMS & 1 & 22 & 23 & & $<0.05^{*}$ \\
& MVR & 10 & 26 & 36 & & \\
\hline Chronic bronchitis & SMS & 3 & 20 & 23 & 1.77 & NS \\
& MVR & 10 & 26 & 36 & & \\
\hline Dyspnoea & SMS & 20 & 3 & 23 & & NS* \\
& MVR & 34 & 2 & 36 & & \\
\hline Wheeze & SMS & 12 & 11 & 23 & 0.46 & NS \\
& MVR & 22 & 14 & 36 & & \\
\hline Acute chest illness & SMS & 3 & 20 & 23 & 6.34 & $<0.01$ \\
& MVR & 16 & 20 & 36 & & \\
\hline Tobacco smoking & SMS & 0 & 23 & 23 & - & - \\
& MVR & 0 & 36 & 36 & & \\
\hline
\end{tabular}

* Fisher's exact test. vealed a restrictive pattern, reduction of $\mathrm{VC}$, RV, TLC, diffusing capacity and MVV [24] (fig. 1, table 1). The restrictive pattern in both male and female patients confirms the results of several previous studies $[5,9,11,12,25$, 26]. Curti et al. [9] found slight to moderate reduction of VC, TLC and $\mathrm{DL}_{\mathrm{CO}}$ in most of their 16 patients. Cosby et al. [10] found a reduction of $\mathrm{VC}$ in their patients with mitral stenosis. Palmer et al. [5] studied 30 patients with chronic mitral valve disease. They reported a reduction in $\mathrm{VC}$ of approximately $65-80 \%$ of predicted, and reduction of diffusing capacity [5]. Wood et al. [25] studied 23 patients with mitral stenosis pre-operatively and they reported a reduction of VC. Rhodes et al. [26] studied the effect of mitral valve disease on the lung function in 26 patients, and they confirmed the reduction of $\mathrm{VC}$ and transfer factor. The evidence for obstructive airway pattern in this study is in fair agreement with the report of the earlier workers [5, $12,26,27]$. Palmer et al. [5] reported reduction of mean values for the maximal midexpiratory flow rate and an increased airway resistance. Rhodes et al. [26] and Singh et al. [27] reported a reduction of $\mathrm{FEV}_{1}$, and an increase in RV. To a large extent, the restrictive and obstructive patterns in mitral stenosis can be explained on the basis of pulmonary vascular congestions, interstitial oedema and increased pulmonary water [28, 29]. Similar pulmonary function changes were observed in experimental pulmonary oedema in dogs [30].

All of the usual respiratory symptoms have been documented in mitral stenosis. Dyspnoea and shortness of breath during exercise are the most common complaints. In addition, orthopnoea, acute episodic dyspnoea, 
chronic cough, recurrent pulmonary infection, wheezing and haemoptysis may occur [6, $7,14,31]$. These symptoms would suggest disease of the lung. Therefore, the value of assessment of pulmonary function in mitral stenosis was well recognized [5, 10, 11, 26-28]. Earlier workers correlated different pulmonary function data with the clinical severity of the disease, and reported that the reduction of the VC was more in those with the severe disease $[5,9,26]$. The group of patients with SMS had insignificant effort intolerance or mild significant effort intolerance according to Wood's modification of the New York Heart Association classification of the effort intolerance. The group of SMS in this study had a mitral early diastolic closure (MEC) to the value of $30 \mathrm{~mm} / \mathrm{s}$ or more [13]. In general, surgery is deferred in patients with mitral orifice size more than approximately $1.0 \mathrm{~cm}^{2} / \mathrm{m}^{2}$ BSA when assessed by echocardiography [32]. As shown in the present study, the group with SMS had significantly less severe respiratory symptoms than the group of patients with advanced mitral stenosis and required surgery, and also had better values for the pulmonary function data. The MVR group had a significantly higher prevalence of cough phlegm and acute chest illness than the SMS group (table 2). The SMS group had a less restrictive pattern, with FVC significantly higher and a higher $\mathrm{DL}_{\mathrm{CO}}$ as well as less obstructive pattern than the MVR group. Furthermore, the SMS group had significantly higher $\mathrm{FEV}_{1}$ and higher $\operatorname{Vmax}_{50}$ (table 1).

The fact that pathological changes occur in the lungs of patients with mitral stenosis had been generally accepted $[33,34]$. Larrabee et al. [34] described thickening of the capillary basement membrane, scarring and loss of capillaries in post-mortem studies. However, there is no agreement regarding the physiological and the clinical significance of these pulmonary lesions. Some clinicians remain rela- tively unaware of the impact of the cardiac valvular disease on pulmonary function. Long-standing mitral stenosis is known to produce gross pathologic feature of haemosiderosis and stiff parenchymal tissue [35]. The organization of long-standing interstitial and alveolar pulmonary oedema may result in fibrosis and calcification [36]. The arterioles and small muscular arteries show thickening of the media. The pulmonary venules and small veins show initial fibrosis and thickening. Bronchial veins are quite prominent and varices may be present [36-39]. The lungs may therefore be stiffer than normal, and this will predispose to the respiratory symptoms in patients with mitral stenosis.

Several factors are known to contribute to the pathogenesis of airflow obstruction in patients with mitral valve disease. Hypertrophied and hyperplastic airway smooth muscle and increased wall thickness cause heightened bronchial hyperreactivity [40, 41]. It is suggested that pulmonary congestion and epithelial inflammation secondary to repeated respiratory tract infection with or without antigenic stimulation, which activate sensory nerve ending in the oedematous lower airways, cause bronchoconstriction by increasing vagal efferent activity [6, 28, 42, 43]. Mediators released from mast cells, formed blood elements, complement fragments, could also stimulate sensory nerve ending and result in reflex sensitization of bronchomotor tone [44, 45]. The damaged airway epithelial cells activate arachidonic acid metabolism, releasing leukotriene $\mathrm{B}_{4}$ and mediators from mast cells such as 5-hydroperoxyeicosatetraenoic acid, that directly produce bronchospasm [46]. It has been suggested that stimulation of platelets by platelet-activating factor (PAF-Acether) may release inflammatory mediators that directly cause bronchial smooth muscle to contract [47-49]. Rheumatic fever is a consequence of immunologic response or hypersen- 
sitivity reaction, or both to streptococcal antigens, which may affect the bronchial system although its main effect is on the heart [50].

The study confirmed restrictive and obstructive patterns of pulmonary dysfunction. The deterioration in lung function in mitral stenosis correlated with the severity of stenotic valves and correlated with the severity of respiratory symptoms. It is recommended that lung function studies which are non-inva- sive, rapid and relatively inexpensive can provide valuable information in the assessment of valvular heart disease, and the long-term effect on the lung function values.

\section{Acknowledgement}

The authors thank Dr. N.C. Syabbalo, Faculty of Medicine, Kuwait University for helpful advice on the manuscript.

\section{References}

1 Bergy GG, Bruce RA: Discrepancies between subjective and objective responses of mitral commissurotomy. N Engl J Med 1955;253:887-891.

2 Chapman CB, Mitchell JH, Sproule BJ, Polter D, Williams B: Maximal oxygen intake test in patients with predominant mitral stenosis. Circulation 1960;22:4-14.

3 Holmgren A, Jonsson B, Linderholm H, Sjostrand T, Strom G: Physical working capacity in cases of mitral valvular disease in relation to heart volume, total amount of haemoglobin and stroke volume. Acta Med Scand 1958;162:99-122.

4 Frank NR, Cugell DW, Gaensler EA, Ellis LB: Ventilatory studies in mitral stenosis: A comparison with findings in primary pulmonary disease. Am J Med 1953;15:60-76.

5 Palmer WH, Gee JBL, Mills FC, Bate DV: Disturbances of pulmonary function in mitral valve disease. Gen Med Assoc J 1963;89: 744-750.

6 Julian DG: Cardiology. London, Baillière Tindall, 1973, pp 205216.

7 Ross J Jr: Mitral stenosis; in Beeson PB, McDermott W: Textbook of Medicine. Philadelphia, Saunders, 1975, pp 962-967.

8 Parker F Jr, Weiss S: The nature and significance of the structural changes in the lungs in mitral stenosis. Am J Pathol 1936;12:573-798.
9 Curti PC, Cohen G, Castleman B, Scannel JG, Friedlick AL, Mayers GS: Respiratory and circulatory studies of patients with mitral stenosis. Circulation 1953;8:893-904.

10 Cosby RS, Stowell EC Jr, Hartwig WR, Mayo M: Abnormal ventilatory patterns in mitral stenosis. $\mathrm{Br} \mathrm{J}$ Dis Chest 1956;35:633-640.

11 Dogliotti GC, Angelino PF, Brusia A, Garbagni R, Gravosto Mgri G, Menetto E: Pulmonary function in mitral valve disease: Haemodynamic and ventilatory studies. Am J Cardiol 1959;3:28-39.

12 Mustafa KY, Nour MM, Shuhaiber H, Yousof AM: Pulmonary function before and sequentially after valve replacement surgery with correlation to preoperative haemodynamic data. Am Rev Respir Dis 1984;130: 400-406.

13 Yousof AM, Endrus G, Steinhart L, Zyka I: Mitral echocardiography. II. J Kut Med Assoc 1973;7:5-14.

14 Yousof AM, Shafie MZ, Kvachinska G, Al-Yousof AR, Sallam I: Longterm results of valvular replacement in Kuwaities. J Cardiovasc Surg 1981;22:28-34.

15 A statement of the committee of standards for epidemiologic surveys in chronic respiratory disease of the American Thoracic Society. C. LeMaistre, Chairman, New York, National Tuberculosis and Respiratory Disease Association, 1969, p 32.
16 Anderson TW, Brown JR, Hall JW, Shephard RJ: The limitation of linear regression for the prediction of vital capacity and forced expiratory volume. Respiration 1968;25:140158.

17 American Thoracic Society: Standardization of spirometry: 1994 update. Am Rev Respir Dis 1994;152: 1107-1136.

18 Quanjer PH, Tammeling GJ, Cotes JE, Pedersen OF, Peslin R, Yernault JC: Lung volumes and forced expiratory flows: Reports of the working party, standardization of lung function tests, European Community for Steel and Coal. Official statement of the European Respiratory Society. Eur Respir J 1993;6(suppl 16):540.

19 Cotes JE: Lung Function Assessment and Application in Medicine. Oxford, Blackwell Scientific Publications, 1979, p 370.

20 Billiet L, Baisier W, Naedts JP: Effect of size, sex and age on pulmonary diffusing capacity of the normal adult. J Physiol Paris, 1963;55: 199-200.

21 DuBois AB, Botelho SY, Bedell GN, Marshall R, Comroe JH Jr: A rapid plethysmographic method for measuring thoracic gas volume: A comparison with nitrogen washout method for measuring functional residual capacity in normal subjects. $\mathrm{J}$ Clin Invest 1956;35:322-326.

22 Schmidt AM, Cohn JE: Modified body plethysmograph for study of cardiopulmonary physiology. J Appl Physiol 1961;16:935-938. 
23 Hinkle DE, Wiersma W, Jurs SG: Basic Behavioural Statistics. Boston, Houghton Mifflin, 1982.

24 Comroe JH Jr, Forster RE, Dubois $\mathrm{AB}$, Briscoe WA, Carlsen E: The Lung Clinical Physiology and Pulmonary Function Tests. Chicago, Year Book Medical Publishers, 1962.

25 Wood TE, Mcleod P, Anthonisen NR, Macklem PT: Mechanics of breathing in mitral stenosis. Am Rev Respir Dis 1971;104:52-60.

26 Rhodes KM, Evemy K, Nariman S, Gibson GJ: Relation between severity of mitral valve disease and results of routine lung function tests in non-smokers. Thorax 1982;37:751755.

27 Singh T, Dinda P, Chatterjee SS, Riding WD, Patel TK: Pulmonary function studies before and after closed mitral valvotomy. Am Rev Respir Dis 1970;101:62-66.

28 Cortese DA: Pulmonary function in mitral stenosis. Mayo Clin Proc 1978;53:321-326.

29 Hogg JC, Agrawal JB, Gardiner AJS, Palmer WH, Macklem PT: Distribution of airway resistance with developing pulmonary edema in dogs. J Appl Physiol 1972;32:20 24.

30 Williams MH Jr: Effect of ANTUinduced pulmonary edema on the alveolar-arterial oxygen gradient in dogs. Am J Physiol 1953;175:84 86.

31 Wood P: An appreciation of mitral stenosis. Part I and II. BMJ 1954;i: 1051-1113.
32 Braunwald E: Heart Disease: A Textbook of Cardiovascular Medicine. Philadelphia, Saunders, 1992, p 1015.

33 Henry EW: The small pulmonary vessels in mitral stenosis. Br Heart $\mathbf{J}$ 1952;14:406-412.

34 Larrabee WF, Parker RL, Edwards JE: Pathology of intrapulmonary arteries and arterioles in mitral stenosis. Proc Staff Meet Mayo Clin 1952;24:316-323.

35 Heath D, Hicken P: The relation between left atrial hypertension and lymphatic distension in lung biopsies. Thorax 1960;15:54-58.

36 Heath D, Edwards JE: Histological changes in the lung in diseases associated with pulmonary venous hypertension. Br J Dis Chest 1959;53: 8-18.

37 Bland EF, Sweet RH: A venous shunt for advanced mitral stenosis. JAMA 1949;140:1259-1265.

38 Harrison CV: The pathology of the pulmonary vessels in pulmonary hypertension. Br J Radiol 1958;31: 217-226.

39 Arnott WM: The lungs in mitral stenosis. BMJ 1963;2:765-770;823830.

40 Huber HL, Koessler KK: The pathology of bronchial asthma. Arch Intern Med 1922;30:687-760.

41 Folkow B: The haemodynamic consequences of adaptive structural changes of the resistance vessels in hypertension. Clin Sci 1971;41:112.

42 Nadel JA, Widdicombe JG: Reflex control of airway size. Ann NY Acad Sci 1963;109:712-723.

43 Roberts AM, Kaufman MP, Baker DG, Brown JK, Coleridge HM, Coleridge JC: Reflex tracheal contraction induced by stimulation C-fibers in dogs. J Appl Physiol 1981;51: 485-493.
44 Empey DW, Luitinen LA, Jacobs L, Gold WM, Nadel JA: Mechanism of bronchial hyperreactivity in normal subjects following respiratory tract infection. Am Rev Respir Dis 1976; 113:131-139.

45 Nadel JA, Sheppard D: Mechanism of bronchial hyperactivity in asthma; in Weiss EB, Segal MS, Stein M (eds): Bronchial Asthma Mechanisms and Therapeutics. Boston, Little, Brown, 1985, pp 30-36.

46 Regal JF, Pickering RJ: C5a-induced tracheal contraction: Effect of an SRS-A antagonist and inhibitors of arachidonate metabolism. J Immunol 1981;126:313-316.

47 Owen RT: Platelets: A review of selected aspects of their physiology, pharmacology and pathology, with special reference to their role in inflammation and thrombogenesis. Drugs Today 1979;15:487-499.

48 Nachman RL, Weksler BB: The platelet as an inflammatory cell: in Weissman G (ed): The Cell Biology of Inflammation. Amsterdam, Elsevier 1980, p 145.

49 Vargaftig BB, Lefort J, Wal F, Chignard M, Medeiros MC: Non-steroidal anti-inflammatory drugs associated to antihistamine and anti-sterotonin agents with the bronchial and platelet effects of 'platelet activating factor' (PAF-Acether). Eur J Pharmacol 1982;82:121-130.

50 Krause RM: Rheumatic Fever; in Beesan PF, McDermott W (eds): Textbook of Medicine. Saunders, Philadelphia, 1975, pp 300-308. 